\title{
僧帽弁狭窄症に伴う重症心不全合併妊娠に集学的治療が有効 であった一例
}

$\begin{array}{lllllll}\text { 宮 } & \text { 顕 } & \text { 河野 } & \text { 小 } & \text { 小山 } & \text { 泰明 } & \text { 榎本 } \\ \text { 萩谷 } & \text { 圭一 } & \text { 山崎裕一朗 } & \text { 下條 } & \text { 信威 } & \text { 水谷 } & \text { 太郎 }\end{array}$

筑波大学附属病院救急・集中治療部（† 305-8576＼cjkstart茨城県つくば市天久保2-1-1）

Key words: (1) mitral stenosis, (2) alveolar hemorrhage, (3) percutaneous transluminal mitral commissurotomy

\section{はじめに}

先進諸国では妊娠出産年齢における僧帽弁狭窄症は 稀であるが, 発展途上国ではリウマチ性僧帽弁狭窄症 の罹患率が未だ高く，妊産婦の弁疾患のうち最多とさ れる ${ }^{1)}$ 。今回我々は, 妊娠中期に僧帽弁狭窄症による 重症心不全を発症した 20 歳女性に急性期集中治療が 奏功し, 経皮経静脈的僧帽弁交連切開術 (percutaneous transluminal mitral commissurotomy, PTMC) を施行することで妊娠継続，帝王切開術による分婏が 可能であった症例を経験したので報告する。

\section{症 例}

20 歳, タイ人女性。 2 回の正常分婏の既往あり。特 記すべき既往なし。

妊娠 27 週 6 日，咳嗽を主訴に救急外来を受診。末梢 冷感を認め, 全肺野に中等度の湿性ラ音を聴取した。 血圧 $90 / 52 \mathrm{mmHg}$, 心拍数 $119 / \mathrm{min}$ (整), 体温 $38.2^{\circ} \mathrm{C}, \mathrm{SpO}_{2} 90 \%$ (室内気) であり, 精查, 治療目的に 入院した。

血算・生化学検査では貧血と炎症反応上昇 (WBC $14,000 / \mu l$, RBC $2.21 \times 10^{6} / \mu l, \mathrm{Hb} 5.0 \mathrm{~g} / \mathrm{d} l, \mathrm{Ht}$ $16.0 \%, \mathrm{CRP} 6.28 \mathrm{mg} / \mathrm{d} l)$ を認め, 胸部単純 X線写真, 単純 C Tでは両肺に浸潤影を認めた。肺炎が疑われ抗 菌薬治療が開始されたが, 症状は増悪し，血痰を伴う ようになった。貧血に対してトラネキサム酸 $1 \mathrm{~g} /$ day, シデフェロン $240.4 \mathrm{mg} / \mathrm{day} の$ 投与を開始した が, $\mathrm{Hb}$ の増加を認めず, 適宜濃厚赤血球液の輸血を要 した。

心エコー検査で僧帽弁にリウマチ性変化と開放制限 を認め, ドップラー法で僧帽弁平均圧較差 $29 \mathrm{mmHg}$, 僧帽弁弁口面積 $0.93 \mathrm{~cm}^{2}$, 推定右室圧 $71 \mathrm{mmHg}$ であっ たことから, 病態は僧帽弁狭窄症に合併した肺胞出血 と判断し, 28 週 1 日, ICUに入室し肺動脈カテーテル を挿入した。心拍出量 $6.6 \mathrm{l} / \mathrm{min}$, 肺動脈楔入圧 26 $\mathrm{mmHg}$, 肺動脈圧 $55 / 27 \mathrm{mmHg}$, 右室圧 $54 / 2 \mathrm{mmHg}$ であった。

デクスメデトミジン $0.4 \mu \mathrm{g} / \mathrm{kg} / \mathrm{hr}$ で鎮静し, 前負荷 軽減のためにフロセミド $10 \mathrm{mg}$ の適宜投与, 硝酸イソ ソルビド $1 \mathrm{mg} / \mathrm{hr}$ の持続投与と非侵襲的陽圧換気 $\left(\mathrm{F}_{\mathrm{I}} \mathrm{O}_{2}\right.$ 0.5, PEEP $\left.4 \mathrm{cmH}_{2} \mathrm{O}\right)$ を開始した。2,000 $\mathrm{ml}$ dayの尿量が得られ, 心拍数は $80 / \mathrm{min}$ に低下したが, 28 週 2 日の胸部 C $\mathrm{T}$ も肺胞出血の所見が強く, 血痰の 喀出困難, 起座呼吸を呈したため, 28 週 3 日, 気管扱 管し人工呼吸管理を開始した。

ここまでの内科的治療，陽圧換気により循環動態は 安定したが, 妊娠継続には僧帽弁の外科的治療が必要 と判断した。人工心肺を用いた開心術は胎児，母体に とって高侵襲であるため, より低侵襲な PTMCを同日 に施行した。右大腿静脈からのアプローチであったた め, 妊娠に伴う下大静脈圧迫がカテーテル手技の進行 を妨げる可能性があったが, 手技はスムーズに行われ，

Successful multidisciplinary treatment in a case of perinatal severe heart failure due to mitral stenosis

Ken Miya, Satoru Kawano, Yasuaki Koyama, Yuki Enomoto, Keiichi Hagiya, Yuichiro Yamasaki, Nobutake Shimojo, Taro Mizutani

Department of Emergency and Critical Care Medicine, University of Tsukuba (2-1-1 Amakubo, Tsukuba, Ibaraki 305-8576, Japan)

J Jpn Soc Intensive Care Med 2016;23:67-8. 
体位変換などを必要とすることはなかった。

僧帽弁弁口面積は $1.22 \mathrm{~cm}^{2}$ から $1.82 \mathrm{~cm}^{2}$ に拡大し, 心拍出量 $7.5 \mathrm{l} / \mathrm{min}$, 肺動脈楔入圧 $17 \mathrm{mmHg}$, 肺動脈 圧 45/19 mmHg, 右室圧 $46 / 0 \mathrm{mmHg}$ となった。経僧 帽弁圧較差は $16.6 \mathrm{mmHg}$ から $9.5 \mathrm{mmHg}$ に低下し, 術 後血痰は消失した。胸部X線写真の浸潤影も減弱し, 29 週 3 日に人工呼吸管理を終了, 31 週 2 日に退院し た。

外来経過観察期間を経て 37 週 1 日, 硬膜外麻酔法に よる待機的帝王切開術を行い, 2,375 g (Apgar score 7 点/8点)の男児を出産した。

\section{考察}

僧帽弁狭窄症合併妊娠は, 妊娠による循環動態の変 化のため 2 , 胎児では子宮内発育不全, 母体では僧帽 弁圧較差の増大, 肺動脈楔入圧上昇による肺うっ 血 ${ }^{3)}$, および心房細動などの不整脈のリスクとなる。妊娠中 に発症した僧帽弁狭窄症のうちNYHA (New York Heart Association) class IVの重症心不全での胎児死 亡率は $30 \%$, 母体死亡率も $7 \%$ に上る1) とされ妊娠の 終了を考慮する必要があるが, 胎児の発育状況次第で はその判断が難しい。

僧帽弁狭窄症によるうっ血性心不全を発症した場 合, まずは内科的に前負荷軽減, 心拍数管理などを試 みるが, 妊娠継続のため最終的に僧帽弁の外科的治療 を要する場合も多い。周産期における全身麻酔下の開 心術はガイドライン ${ }^{4)}$ 上許容されるが，人工心肺中の 低体温が子宮収縮を誘発すること，本症例のように心 不全非代償期に緊急で施行しなければならないことな どの理由により, 胎児死亡率が $37.9 \%$ に上昇する5) と もいわれている。その点PTMCは胎児, 母体に低侵襲 なカテーテル手技であり, 術後速やかな循環動態の改 善が期待できるため, 周産期の施行例が散見される。 僧帽弁の癒着, 石灰化, 僧帽弁閉鎖不全の合併などの 理由で施行不能な場合もあるが, 施行例の短期予後は 良好で, 胎巟死亡は $4.8 \%$ と報告されている5)。胎児の 放射線被曝によるリスク軽減のため, 腹部を放射線遮 蔽する, 器官形成期を避ける, 経食道心エコーを用い
るなどの工夫もなされている。

妊娠中に肺高血圧, 重度の肺胞出血, NYHA class IVの重症心不全を呈するような僧帽弁狭窄症合併妊娠 においても, 集中治療医を中心に呼吸, 循環動態の安 定化がなされた上で, PTMCなどの循環器カテーテル インターベンション手技を行うことで，心不全症状の 劇的な改善と, 待機的分娩が可能となると考えられた。

\section{結 語}

肺胞出血を機に診断された僧帽弁狭窄症合併妊娠に 対し, 適切な急性期集中治療と PTMCの施行により胎 児, 母体ともに良好な転帰を得た。僧帽弁狭窄症合併 妊娠においては, 集中治療科, 循環器科, 産科および 新生児科が連携し, 胎児と母体双方にとって低侵襲な 集学的治療を考慮すべきである。

本稿の要旨は, 第 40 回日本集中治療医学会学術集会 $(2013$ 年, 長野)において発表した。

本稿のすべての著者には規定されたCOIはない。

\section{文 献}

1) Reimond SC, Rutherford JD. Clinical practice. Valvular heart disease in pregnancy. N Engl J Med 2003;349:52-9.

2) Thornburg KL, Jacobson SL, Giraud GD, et al. Hemodynamic changes in pregnancy. Semin Perinatol 2000;24:11-4.

3) Carabello BA. Modern management of mitral stenosis. Circulation 2005;112:432-7.

4) 日本循環器学会, 日本産科婦人科学会, 日本小児循環器学 会, 他. 循環器病の診断と治療に関するガイドライン $(2009$ 年度合同研究班報告）心疾患患者の妊娠 - 出産の適応, 管 理に関するガイドライン (2010年改訂版). Available from: http://www.j-circ.or.jp/guideline/pdf/JCS2010niwa.h.pdf (2015年 2 月閲覧)

5) de Souza JA, Martinez EE Jr, Ambrose JA, et al. Percutaneous balloon mitral valvuloplasty in comparison with open mitral valve commissurotomy for mitral stenosis during pregnancy. J Am Coll Cardiol 2001;37: 900-3.

受付日 2014 年 12 月 8 日 採択日 2015 年 5 月 8 日 